\title{
Paepalanthus aleurophyllus, a new species of Eriocaulaceae from Minas Gerais, Brazil
}

\author{
M. Trovó ${ }^{1}$, L. Echternacht ${ }^{2}$, P.T. Sano ${ }^{3}$, F.N. Costa ${ }^{4}$
}

\section{Key words}

Campo Rupestre

conservation

Paepalanthoideae

Pico do Itambé State Park

taxonomy

\begin{abstract}
We describe and illustrate Paepalanthus aleurophyllus (Eriocaulaceae, Paepalanthoideae). The species is narrowly distributed, restricted to the Pico do Itambé in Minas Gerais, Brazil. Detailed comparisons are made with $P$. diplobetor and P. ciliolatus. Paepalanthus aleurophyllus is distinguished by its densely ciliated leaves with dolabriform to fusiform trichomes in the adaxial leaf surface, conspicuous venation on the abaxial leaf surface, trichomes between the scape ribs, general habit, and other floral features. We provide detailed line drawings and commentaries on distribution, ecology, and conservation.
\end{abstract}

Published on 27 August 2013

\section{INTRODUCTION}

Paepalanthus Mart., the largest genus of Neotropical Eriocaulaceae, is also the largest genus of Brazilian Angiosperms (Forzza et al. 2010). The majority of the c. 360 Brazilian species are endemic to the country and are mainly distributed in two centres of morphological and taxonomic diversity: the Espinhaço Range (campos rupestres) and the Savannas (Cerrados) (Giulietti \& Hensold 1990, Stützel 1998, Giulietti et al. 2005). Although polyphyletic, Paepalanthus is morphologically easily distinguished from the other genera by its pistillate flowers with free petals, isostemonous flowers, and gynoecium with stigmatic and nectariferous branches inserted at the same level (Giulietti \& Hensold 1990, Stützel 1998, Andrade et al. 2010, Trovó et al. 2013).

The taxonomy within Paepalanthus is, however, obscure with regard to both species identification and delimitation. Throughout the 20th century, Silveira $(1908,1928)$ and Moldenke (e.g. $1960,1977)$ described hundreds of species based on few specimens without providing any identification key or detailed comparison. The few comprehensive taxonomic revisions are limited to the small well-defined categories, such as Paepalanthus subg. Xeractis Körn. (Hensold 1988), Paepalanthus subg. Platycaulon Körn. (Tissot-Squalli 1997), and Paepalanthus sect. Diphyomene Ruhland (Trovó \& Sano 2010a, 2011).

Paepalanthus ser. Paepalanthus (= Paepalanthus [unranked] Variabiles Ruhland) comprises c. 200 species grouped by its rosulate leaves and scapes in a seemingly axillary position with each bearing a single capitulum of trimerous flowers (Ruhland 1903). The morphological variation within the group is broad and remains to be explored. The circumscription of many spe-

\footnotetext{
Departamento de Botânica, Instituto de Biologia, Universidade Federal do Rio de Janeiro, Av. Carlos Chagas Filho 373, 21941-590, Rio de Janeiro, RJ, Brasil; corresponding author e-mail: martrovo@gmail.com.

2 Departamento de Botânica, Instituto de Ciências Biológicas, Universidade Federal de Minas Gerais, Av. Antônio Carlos 6627, Pampulha, 31270-901, Belo Horizonte, MG, Brasil.

${ }^{3}$ Laboratório de Sistemática Vegetal, Departamento de Botânica, Instituto de Biociências, Universidade de São Paulo, Rua do Matão 277, 05508-900, São Paulo, SP, Brasil.

${ }^{4}$ Departamento de Ciências Biológicas, Universidade Federal dos Vales do Jequitinhonha e Mucuri, Campus JK, Rodovia BR-367, 39100-000, Diamantina, MG, Brasil.
}

cies relies on a few unstable characters and a full taxonomic revision is a distant ambitious goal. Therefore, advances in its taxonomy have been achieved in isolated manuscripts, usually derived from floristic inventories or fieldwork (e.g. Trovó \& Sano 2010b, Trovó et al. 2012). Based on careful analysis of the historical collections of Eriocaulaceae, we describe the following species.

\section{TAXONOMIC TREATMENT}

\section{Paepalanthus aleurophyllus Trovó, sp. nov. - Fig. 1}

Typus: V.C. Souza 8400, P.H. Miyagi, J.P. Souza (holo SPF; iso B, ESA, HUEFS, NY, P, UB, UFMG), Brazil, Minas Gerais, Santo Antônio do Itambé, "Início da estrada para o pico do Itambé. 800-1200 msm.", 12 Mar. 1995.

Etymology. The epithet 'aleurophyllus' alludes to the floury appearance of the leaves, due to its short and dolabriform to fusiform trichomes, which are unusual in Paepalanthus.

Herbs. Stem short, not thickened, 1-2 cm long. Rhizome absent. Leaves arranged in a rosette, flat, lanceolate, chartaceous, $5-9.5$ by $0.4-0.7 \mathrm{~cm}$ long, green, abaxial surface glabrous with conspicuous venation, adaxial surface with short (c. $0.15-0.30$ $\mathrm{mm}$ long), basally attached dolabriform to fusiform trichomes, margins densely ciliate, apex acute. Spathes chartaceous, 1-3 $\mathrm{cm}$ long, with short fusiform trichomes, apex acute, oblique opened. Scapes free, c. 6-30 per plant, arranged in a seemingly axillary position, $4.5-11.5 \mathrm{~cm}$ long, multicostate, with short, fusiform to filamentous trichomes between the ribs. Capitula $0.5-1 \mathrm{~cm}$ diam, brown involucre, white disc. Involucral bracts in 2-4 series, ovate, c. $3 \mathrm{~mm}$ long, brown, pilose to glabrescent on abaxial surface, ciliate to glabrescent toward the acute to mucronate apex. Flowers 3-merous, c. 40 per capitula: 30 staminate flowers, 10 pistillate flowers. Floral bracts oblong, c. $3 \mathrm{~mm}$ long, glabrous on both surfaces, ciliate toward the acute apex, brown. Staminate flowers c. $4 \mathrm{~mm}$ long; pedicel c. $0.5 \mathrm{~mm}$ long, with long, filamentous trichomes; sepals fused at the base, obovate, c. $3 \mathrm{~mm}$ long, pilose on abaxial surface apex to glabrescent, ciliate toward the obtuse apex, stramineous to dark brown; corolla tubular, glabrous, membranaceous, cream, unlobed; stamens c. $2 \mathrm{~mm}$ long, adnate at base to the corolla, anthers cream; pistillodes 3 , elongated, papillose.

(c) 2013 Naturalis Biodiversity Cente

You are free to share - to copy, distribute and transmit the work, under the following conditions:

Attribution: $\quad$ You must attribute the work in the manner specified by the author or licensor (but not in any way that suggests that they endorse you or your use of the work).

Non-commercia:

You may not use this work for commercial purpose

No derivative works: You may not alter, transform, or build upon this work

For any reuse or distribution, you must make clear to others the license terms of this work, which can be found at http://creativecommons.org/licenses/by-nc-nd/3.0/legalcode. Any of the above conditions can be waived if you get permission from the copyright holder. Nothing in this license impairs or restricts the author's moral rights. 
Pistillate flowers c. $4 \mathrm{~mm}$ long, sessile; sepals fused at base, oblong to oblanceolate, c. $4 \mathrm{~mm}$ long, stramineous to brown, pilose on abaxial surface apex to glabrescent, ciliate toward the obtuse apex, thickening during fruit maturation; petals membranaceous, oblong to navicular, c. $3 \mathrm{~mm}$ long, stramineous to cream, hyaline to opaque, pilose on abaxial surface apex to glabrescent, ciliate toward the obtuse apex; gynoecium c. $3 \mathrm{~mm}$ long at anthesis, stigmatic branches shortly bifid at the apex, twice longer than the nectariferous branches; staminodes 3, scale-like. Fruit a loculicidal capsule.
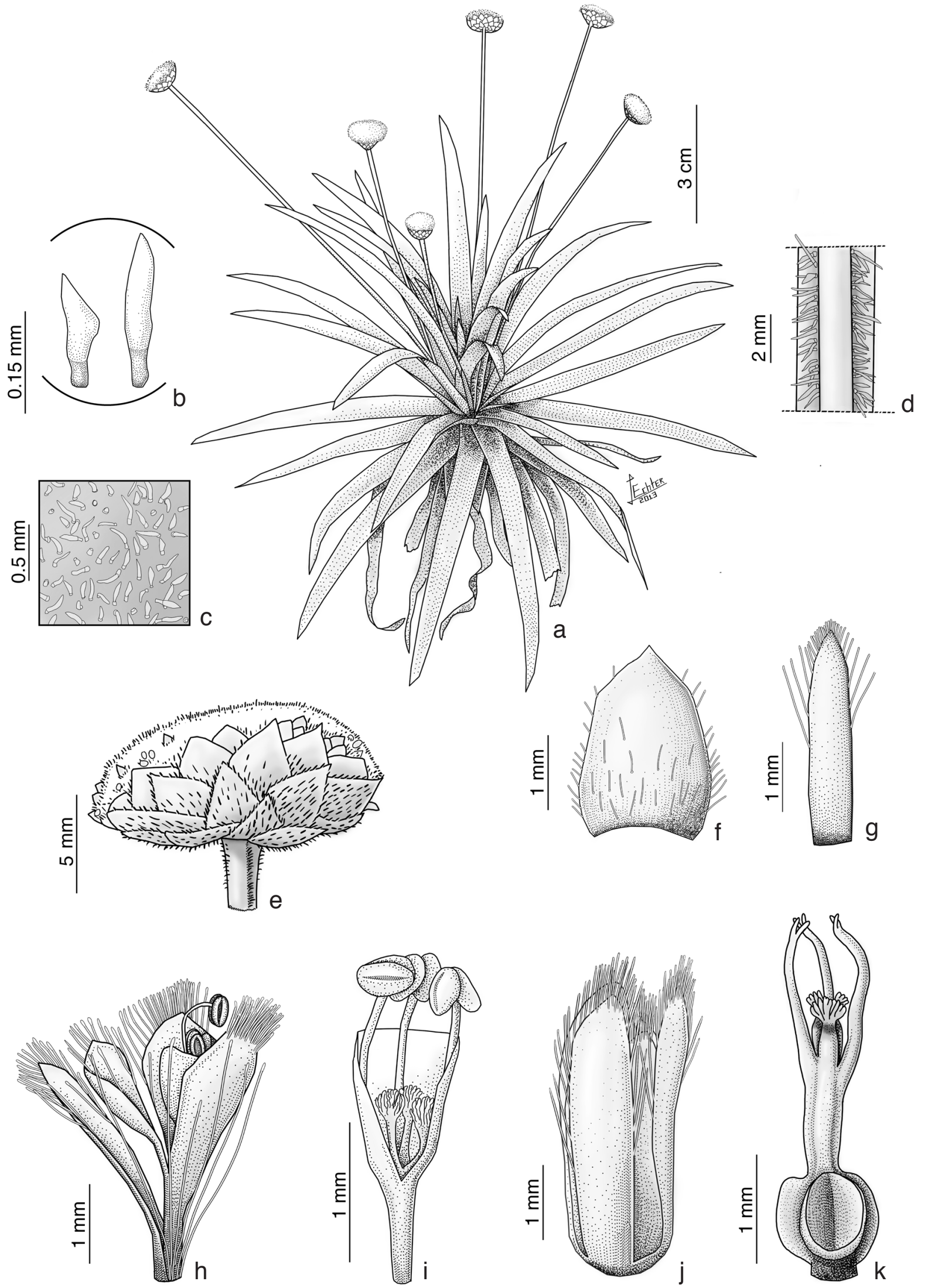

Fig. 1 Paepalanthus aleurophyllus Trovó. a. Habit; b. two forms of leaf hairs, on the left, a dolabriform trichome, on the right, a fusiform trichome; c. adaxial leaf surface detailing the floury indument; $d$. scape detailing the trichomes between the ribs; e. capitula detail; f. involucral bract abaxial surface; $g$. floral bract abaxial surface; h. staminate flower; i. staminate flower with sepals and pedicel removed, and opened corolla; j. pistillate flower; k. gynoecium with seeds released (Souza et al. 8400, SPF). 
Distribution \& Conservation - Paepalanthus aleurophyllus is known from a few populations occurring in Santo Antônio do Itambé (Minas Gerais). These populations are restricted to a mountain known as Pico do Itambé, in the Espinhaço Range. This mountain, which is a conservation unit, hosts many endemic species of Eriocaulaceae. Trovó et al. (2011) described Paepalanthus hirtellus Trovó, Echtern. \& Sano, restricted to the Pico do Itambé State Park. Silveira (1928) described various species found only in this area or also in adjacent mountains between the Pico do Itambé and the Chapada do Couto in Minas Gerais. As the region has been poorly collected, it is possible that these species are distributed more widely than currently known.

Paepalanthus aleurophyllus occurs on slopes of Pico do Itambé, which is on the boundary of the Atlantic Forest and Cerrado biomes. Nowadays, the natural habitats of the surroundings of Pico do Itambé State Park are quite fragmented, mainly because of agriculture and pasture, and the forested areas are limited to small remnants and river banks. Considering its narrow distribution, the species is endangered according to criteria B1, B2a i, and B2a of the IUCN (2011).

Habitat \& Ecology - The species grows in shady places, on riparian understories. According to the herbarium sheets, individuals occupy humid, argillaceous soils. This is not very common within Paepalanthus, as most of the species occur in drier soils in open areas. The flowering period probably extends from the beginning of February to May. The species was found with fully developed flowers and fruits between March and April, coinciding with the end of the rainy period.

Morphological affinities - We place $P$. aleurophyllus in Paepalanthus subg. Paepalanthus due to its simple scapes, trimerous flowers, staminate flowers with glabrous corolla, and capsular fruits. A more precise placement within Ruhland (1903) classification leads to Paepalanthus ser. Paepalanthus, as the species has leaves disposed in rosette and scapes in a seemingly axillary position. Recent phylogenetic studies indicated that $P$. ser. Paepalanthus is polyphyletic (Andrade et al. 2010, Trovó et al. 2013). We decided, however, to provisionally include the species into this category until a more stable classification is available.

The ciliate leaves with dolabriform to fusiform trichomes on the adaxial surface, conferring a farinaceous appearance, the conspicuous venation on the abaxial surface, and the trichomes between the scape ribs are a very rare character set within Paepalanthus. Jointly with the general habit of the species and some floral features, such as the obtuse sepals of the staminate flower, they are unique attributes to distinguish $P$. aleurophyllus as a new taxon. Among the congeneric species, $P$. aleurophyllus is morphologically similar to $P$. diplobetor Ruhland and $P$. ciliolatus Ruhland, both species also belonging to Paepalanthus ser. Paepalanthus.

Paepalanthus aleurophyllus and $P$. diplobetor have approximately the same general habit, given by the length of leaves and scapes (c. $3.5-9.5 \mathrm{~cm}$ and c. $4.5-11.5 \mathrm{~cm}$, respectively), have lanceolate and pilose leaves, pilose spathes c. 1-3 cm, and brown involucral bracts. In addition to the diagnostic characters, $P$. aleurophyllus can be differentiated by its longer leaves of $5-9.5 \mathrm{~cm}$ (vs $3-5.5 \mathrm{~cm}$ ), pubescent with trichomes shorter than $1 \mathrm{~mm}$ long (vs lanose with trichomes up to $5 \mathrm{~mm}$ long), spathes pilose as the leaves (vs lanose spathes), multicostate scapes (vs tricostate) and wider capitula of $0.5-1 \mathrm{~cm}(\mathrm{vs} 0.4-0.5 \mathrm{~cm}$ ). The species are allopatric, as $P$. diplobetor presents a southern distribution, occurring on ferruginous campos rupestres, in the Quadrilátero Ferrífero (Minas Gerais).

Another species similar to $P$. aleurophyllus is $P$. ciliolatus, also from the Quadrilátero Ferrífero. Morphological affinities are the pilose and ciliate leaves of c. $5-13 \mathrm{~cm}$, the pilose scapes and spathes, and the brown involucral bracts. However, $P$. aleurophyllus has lanceolate, short-ciliate leaves (vs linear, long-ciliate), scapes of shorter length $(4.5-11.5 \mathrm{~cm}$ vs $10-35$ $\mathrm{cm})$, and shorter spathes (1-3 cm vs $4-7 \mathrm{~cm})$.

Additional specimens examined. BrazIL, Minas Gerais, Santo Antônio do Itambé, G. Hatschbach 27512 (RFA), 9 Sept. 1972; A.M. Giulietti CFCR 7787, N.L. Menezes, M. Meguro (SPF), 1 Apr. 1985

Note - Paepalanthus aleurophyllus is distinguished from other Paepalanthus by its densely ciliate leaves with dolabriform to fusiform trichomes on the adaxial surface, conspicuous venation on the abaxial leaf surface, and its trichomes between the scape ribs. The general habit and floral features, such as the obtuse sepals of the staminate flowers are also useful for its identification.

Acknowledgements Financial support was provided by Alexander von Humboldt Foundation, ALV-2013 (UFRJ-PR2), FAPERJ (E26/112.476/2012) to M. Trovó; CAPES to L. Echternacht (PNPD 2805/09-0); FAPEMIG (CRAAPQ 01077-08) to F.N. Costa; CNPq (Proc. 308300/2012-2).

\section{REFERENCES}

Andrade MJG, Giulietti AM, Rapini A, Queiroz LP, Conceição AS, et al. 2010 A comprehensive molecular phylogenetic analysis of Eriocaulaceae: evidence from nuclear ITS and plastid psbA-trnH and trnL-trnF DNA sequences. Taxon 59: 379-388.

Forzza RC, Baumgratz JFA, Costa A, Hopkins M, Leitman PM, et al. 2010 Angiospermas do Brasil: Catálogo de Plantas e Fungos do Brasil vol. 1: 84-85. Jardim Botânico do Rio de Janeiro, Rio de Janeiro

Giulietti AM, Harley RM, Queiroz LP, Wanderley MGL, Van den Berg C. 2005. Biodiversidade e conservação das plantas no Brasil. Megadiversidade 1: 52-61.

Giulietti AM, Hensold N. 1990. Padrões de distribuição geográfica dos gêneros de Eriocaulaceae. Acta Botanica Brasilica 4: 133-159.

Hensold N. 1988. Morphology and systematics of Paepalanthus subgen. Xeractis (Eriocaulaceae). Systematic Botany Monographs 23. The American Society of Plant Taxonomists, Michigan.

IUCN Standards Petitions Sub-committee. 2011. Guidelines for using the IUCN Red List Categories and Criteria, Version 9.0. http://www.iucn.org (accessed on 13 March 2013).

Moldenke H. 1960. Notes on new and noteworthy plants XXV. Phytologia 7: 119-123.

Moldenke H. 1977. Notes on new and noteworthy plants XCIX. Phytologia 36: 49-53.

Ruhland W. 1903. Eriocaulaceae. In: Engler A(ed), Das Pflanzenreich. Regni vegetabilis conspectus 4, heft 30: 1-294. Engelmann, Leipzig.

Silveira AA. 1908. Flora e serras Mineiras. Imprensa Official, Belo Horizonte. Silveira AA. 1928. Floralia Montium, vol. 1. Imprensa Official, Belo Horizonte. Stützel T. 1998. Eriocaulaceae. In: Kubitzki K (ed), The families and genera of vascular plants IV - flowering plants: Monocotyledons - Alismatanae and Comelinanae (except Gramineae): 197-207. Springer Verlag, Berlin. Tissot-Squalli MLH. 1997. Monographische Bearbeitung von Paepalanthus subgenus Platycaulon. Dissertationes Botanicae 280. Cramer, Berlin.

Trovó M, Andrade MJG, Sano PT, Ribeiro PL, Van den Berg C. 2013. Molecular phylogenetics and biogeography of Neotropical Paepalanthoideae with emphasis on Brazilian Paepalanthus (Eriocaulaceae). Botanical Journal of the Linnean Society 171: 225-243.

Trovó M, Echternacht LA, Sano PT. 2011. Paepalanthus hirtellus, a new species of Paepalanthus subsection Actinocephaloides (Eriocaulaceae) from Minas Gerais, Brazil. Phytotaxa 15: 26-32.

Trovó M, Echternacht LA, Sano PT. 2012. Paepalanthus sphaeroides, a new species of Eriocaulaceae from the Atlantic Forest, Brazil. Blumea 57: 105-108.

Trovó M, Sano PT. 2010a. Taxonomic survey of Paepalanthus section Diphyomene (Eriocaulaceae). Phytotaxa 14: 49-55.

Trovó M, Sano PT. 2010b. Nomenclatural and taxonomic changes in Paepalanthus (Eriocaulaceae) from São Paulo and Minas Gerais, Brazil. Kew Bulletin 65: 275-278.

Trovó M, Sano PT. 2011. Five new and narrowly distributed species of Paepalanthus section Diphyomene (Eriocaulaceae) from Central Brazil. Systematic Botany 36: 610-620. 